\title{
DISTRIBUTION AND HABITAT OF THE MALAYSIAN SPECIES OF LEJEUNEA (MARCHANTIOPHYTA: LEJEUNEACEAE), WITH DESCRIPTION OF LEJEUNEA TAMASPOCSII SP. NOV.
}

\author{
GAIK EE LEE \& S. RobBERT GRADSTEIN
}

\begin{abstract}
We analyze the geographical and elevational ranges and the habitats of 30 species and two varieties of Lejeunea Lib. recorded from Malaysia. The greatest diversity of Lejeunea in Malaysia is found on Mt. Kinabalu with 27 species. The majority of the species are Malesian in distribution with a high number (8) belonging to the West Malesian element. Widely distributed species are often autoicous and produce spores freely; those with narrow distributions are more often dioicous and rarely produce spores. Dispersal of dioicous species seems to be promoted by asexual reproduction, being more common in wide-ranging dioicous species than in narrow-ranging ones. Endemism is $10 \%$ with three species being known only from Mt. Kinabalu. Range sizes of species decrease towards higher elevation and endemic species occur exclusively in the mountains. About half of the species occur in the lower montane rainforest belt, which is the elevational zone with the highest diversity of Lejeunea in Malaysia. The majority of the species are epiphytes, either corticolous or ramicolous. One species (L. dimorpha) is an obligate epiphyll. The new species Lejeunea tamaspocsii G. E. Lee is described and two new combinations, L. dipterota (Eifrig) G. E. Lee and L. exilis var. abnormis (Herzog) G. E. Lee, are proposed.
\end{abstract}

Key words: dispersal, endemism, Lejeunea, liverworts, Malaysia, Malesia, phytogeography, range size, substrate preference, tropical rainforest

Gaik Ee Lee, School of Environmental and Natural Resource Sciences, Faculty of Science and Technology, Universiti Kebangsaan Malaysia,43600, Selangor, Malaysia; e-mail: gaikee0808@hotmail.com

S. Robbert Gradstein, Muséum National d'Histoire Naturelle, Department Systématique et Evolution, C.P. 39 , 57 rue Cuvier, 75231 Paris cedex 05, France; e-mail: gradstein@mnhn.fr

\section{INTRODUCTION}

The genus Lejeunea Lib. with about three hundred currently accepted species is one of the largest genera of the family Lejeuneaceae (Marchantiophyta). A worldwide monograph or a revision of the genus for tropical Asia or for parts of that region does not exist. Current knowledge of $\mathrm{Le}$ jeunea in Southeast Asia has mainly been based on the outdated treatments of Stephani (1915) and Eifrig (1937) and on various regional floristic studies (for references see Lee in press). Useful notes on selected species from Malaysia, especially from Mt. Kinabalu, and some preliminary keys were provided by Mizutani (e.g., 1963, 1966, 1970). Furthermore, several Malaysian Lejeunea species were described and illustrated by Zhu and So (2001) in their comprehensive study of the epiphyllous liverworts of China.
In a taxonomic revision of the genus Lejeunea in Malaysia, Lee (in press) described 30 species and two varieties from Malaysia. The goal of the present paper is to explore the geographical and altitudinal ranges as well as the substrate preferences of the species of Lejeunea recorded from Malaysia. In addition, a new species from Malaysia is presented.

\section{PHYTOGEOGRAPHY}

Based on their geographical ranges, the Lejeunea species of Malaysia can be classified into five phytogeographical groups (Tables $1 \& 2$ ).

1. PANTROPICAL SPECIES. This group includes only Lejeunea flava (Sw.) Nees, a very widely distributed species occurring throughout the tropics 
Table 1. Number of Lejeunea taxa (species, varieties) per distribution type in Malaysia. Distribution types according to Aryanti and Gradstein (2007).

\begin{tabular}{lcc}
\hline Distribution type & Number of taxa & Percentage (\%) \\
\hline Pantropical & 1 & 3 \\
Paleotropical & 3 & 9 \\
Tropical Asiatic & 7 & 22 \\
Malesian & 18 & 56 \\
Endemic & 3 & 10 \\
\hline Total & 32 & 100 \\
\hline
\end{tabular}

and subtropics, between approximately $30^{\circ} \mathrm{N}$ and $30^{\circ} \mathrm{S}$ lat., ranging from the southeastern U.S.A., Caribbean and Mexico southward to northern Argentina, furthermore in Africa, Macaronesia and along the coast of $\mathrm{W}$ Europe, and in Asia from China and Japan southeastwards to Australia, New Zealand and Oceania (Schuster 1980; Zhu \& So 2001).

2. PALEOTROPICAL SPECIES. The paleotropical region includes tropical Africa, tropical Asia and

Table 2. Geographical distribution and dispersal of Malaysian Lejeunea species. A - Autoicous, D - Dioicous, E - Endemic, M - Malesian, Pan - Pantropical, Pal - Paleotropical, TA - Tropical Asiatic, WM - West Malesian.

\begin{tabular}{|c|c|c|c|c|c|}
\hline \multirow{2}{*}{ Taxa } & \multirow{2}{*}{$\begin{array}{c}\text { Geographical } \\
\text { distribution }\end{array}$} & \multirow{2}{*}{ Sexuality } & \multirow{2}{*}{$\begin{array}{l}\text { Vegetative } \\
\text { propagules }\end{array}$} & \multicolumn{2}{|c|}{ Geographical distribution in Malaysia } \\
\hline & & & & Peninsular Malaysia & East Malaysia \\
\hline Lejeunea alata* & Pal & A & - & + & + \\
\hline L. albescens & $\mathrm{M}$ & $\mathrm{D}$ & - & + & + \\
\hline L. anisophylla & Pal & A & - & + & + \\
\hline L. apiculata & TA & A & - & - & + \\
\hline L. cocoes $^{*}$ & TA & $\mathrm{D}$ & + & + & + \\
\hline L. compacta $^{* *}$ & TA & $\mathrm{D}$ & - & - & + \\
\hline L. contracta & $\mathrm{E}$ & $\mathrm{D}$ & - & - & + \\
\hline L. dimorpha* & M & A & + & + & + \\
\hline L. dipterota ${ }^{* *}$ & WM & $\mathrm{D}$ & - & - & + \\
\hline L. discreta & $\mathrm{TA}$ & $\mathrm{D}$ & - & + & + \\
\hline L. eifrigii & TA & A & - & + & + \\
\hline L. exilis var. exilis & TA & $\mathrm{D}$ & + & - & + \\
\hline L. exilis var. abnormis ${ }^{*}$ & WM & $\mathrm{D}$ & + & + & - \\
\hline L. flava & Pan & A & - & + & + \\
\hline L. fleischeri* & WM & $\mathrm{D}$ & - & + & - \\
\hline L. $_{\text {gradsteinii }}{ }^{* *}$ & E & $\mathrm{D}$ & - & - & + \\
\hline L. kinabalensis & M & $\mathrm{D}$ & - & - & + \\
\hline L. lumbricoides & $\mathrm{M}$ & $\mathrm{D}$ & - & + & + \\
\hline L. micholitzii ${ }^{*}$ & WM & $\mathrm{D}$ & + & + & + \\
\hline L. microloba & $\mathrm{M}$ & $\mathrm{D}$ & - & - & + \\
\hline L. mimula & $\mathrm{M}$ & $\mathrm{D}$ & - & - & + \\
\hline L. mizutanii & WM & $\mathrm{D}$ & - & - & + \\
\hline L. papilionacea* & Pal & $\mathrm{A}$ & - & + & + \\
\hline L. patersonii & $\mathrm{M}$ & $\mathrm{D}$ & - & + & - \\
\hline L. patriciae & WM & $\mathrm{D}$ & + & + & - \\
\hline L. pectinella & E & $\mathrm{D}$ & - & - & + \\
\hline L. sordida & M & $\mathrm{D}$ & + & + & + \\
\hline L. stephaniana & WM & $\mathrm{D}$ & - & - & + \\
\hline L. tamaspocsii ${ }^{* * *}$ & E & A & - & + & + \\
\hline L. tuberculosa* & TA & $\mathrm{D}$ & + & + & + \\
\hline L. umbilicata* & $\mathrm{M}$ & $\mathrm{D}$ & + & + & + \\
\hline L. utriculata & WM & $\mathrm{D}$ & - & - & + \\
\hline
\end{tabular}

${ }^{*}$ new to Peninsular Malaysia, ${ }^{* *}$ new to East Malaysia 
the tropical Pacific region except for the Galapagos Is. and Cocos I. which are part of tropical America. Four widespread paleotropical species are recorded in Malaysia, viz. L. alata Gottsche, L. anisophylla Mont., L. papilionacea Steph. and L. tuberculosa Steph. Lejeunea papilionacea was formerly regarded as being restricted to Africa but is now known to occur in Asia and the Pacific region, where the species had been described under at least three different names [L. diversitexta (Steph.) Mizut., L. herzogii Mizut. and Cardiolejeunea cardiantha R. M. Schust. \& Kachroo]. Lejeuna anisophylla is very similar to the neotropical L. adpressa Nees, the only difference between them being the number of oil bodies per cell (ReinerDrehwald 2009; Pócs 2010).

3. Tropical Asiatic Species. Species belonging to this distribution type [L. apiculata Sande Lac., L. cocoes Mitt., L. compacta (Steph.) Steph., L. discreta Lindenb., L. eifrigii Mizut., L. exilis (Reinw. et al.) Grolle] are ranging from India, Indochina and Japan to Malaysia, Indonesia, the Philippines, Papua New Guinea and the Pacific region. The tropical Asiatic taxa $(22 \%)$ are the second largest phytogeographic group in Malaysia, after the Malesian ones.

4. MALESIAN SPECIES. The species of this group extend from Sumatra eastwards to New Guinea and sometimes into the western Pacific region. They include the largest number of $\mathrm{Ma}$ laysian Lejeunea taxa (56\%). Almost half of them ( 8 species, 1 variety) are found in the western Malesian region (Table 2), occurring essentially west of Wallace's line and ranging from Sumatra to Borneo (and sometimes to the Philippines). They include L. dipterota (Eifrig) G. E. Lee ${ }^{1}$, L. exilis var. abnormis (Herzog) G. E. Lee ${ }^{2}$, L. fleischeri (Steph.) Mizut., L. micholitzii Mizut., L. mizutanii Grolle, L. patriciae Schäfer-Verw., L. stephaniana Mizut., L. tamaspocsii G. E. Lee and L. utriculata

\footnotetext{
1 Lejeunea dipterota (Eifrig) G. E. Lee, comb. nov. (BASIONYM: Taxilejeunea dipterota Eifrig, Ann. Bryol. 9: 96. 1937).

2 Lejeunea exilis (Reinw., Blume \& Nees) Grolle var. $a b-$ normis (Herzog) G. E. Lee, comb. et stat nov. (BASIONYM: Byssolejeunea abnormis Herzog, Hedwigia 80: 84. 1941).
}

(Steph.) Mizut. The remaining Malesian species (9) are widespread throughout the Malesian region and may extend to the western portion of the Pacific region. East Malesian species, occurring east of Wallace's line (from Sulawesi eastwards), are essentially lacking in Malaysia. In a study on the geographical distribution of the liverworts of Sulawesi, Aryanti and Gradstein (2007) found a significantly greater number of East Malesian than West Malesian species in Sulawesi (13 vs. 2), thus supporting the biogeographical separation between Sulawesi and Borneo by the Wallace's line. The absence of East Malesian Lejeunea species in Malaysia may be further support for the effectiveness of the Wallace line as a phytogeographical barrier; however, this needs further work on the Lejeunea species in eastern Malesia, which are poorly studied.

5. ENDEMIC SPECIES. According to the present study, three species are endemic to Malaysia: L. contracta Mizut., L. gradsteinii G. E. Lee et al. and L. pectinella Mizut. All three are only known from Mt. Kinabalu (Sabah). The rate of endemism in bryophytes varies depending on the age of the area and the taxa, as well as the evolutionary history and dispersal ability of the concerned taxonomic groups (Piippo \& Koponen 1997). Unsurprisingly, the number of endemics is usually reduced following taxonomic revisions and monographic studies, due to increased synonymy (e.g., Gradstein 1994; Pócs 1988, 2008). Also, further exploration may lead to reduction of the number of endemic taxa. For example, L. patriciae, which was regarded as endemic to Peninsular Malaysia, has recently been collected in Sumatra, Indonesia (Schäfer-Verwimp 2006).

The data on the sexuality of the species show that the majority of the Lejeunea species of Malaysia are dioicous, having unisexual spores (Table 2). Autoicous species (spores bisexual) include L. alata, L. anisophylla, L. apiculata, L. dimorpha, L. eifrigii, L. flava, L. papilionacea and L. tamaspocsii. Several authors have suggested that autoicous species may have wider ranges than dioicous ones based on the assumption that successful migration is easier in species with bisexual spores than in species with unisexual spores (e.g., 
van Zanten \& Pócs 1981; Longton \& Schuster 1983). This hypothesis was supported by Gradstein et al. (1983) and van Zanten and Gradstein (1988) who found that transoceanic tropical liverwort species are significantly more often monoicous than endemic ones. Moreover, Longton and Schuster (1983) suggested that spores are more freely produced in monoicous taxa than in dioicous ones, thus enhancing dispersal in the monoicous ones. All this seems to hold for the Malaysian Lejeuneas: widely distributed species tend to be autoicous and produce spores freely (L. alata, L. anisophylla, L. apiculata, L. eifrigii, L. flava, L. papilionacea) while species with narrow ranges are more often dioicous and rarely produce spores (e.g., L. fleischeri, L. kinabalensis, L. mizutanii, L. stephaniana, L. utriculata).

It has also been suggested that asexual reproduction may increase the chances of successful long-range dispersal in species with unisexual populations (e.g., Heinrichs et al. 2006). This holds to a large extent for the Lejeunea species of Malaysia (Table 2). Among 8 species of Malaysian Lejeunea with asexual propagules, 7 are dioicous and the majority of these (5) are widespread species (Malesian, SE Asian or paleotropical). In contrast, dioicous species without asexual propagules usually have more restricted ranges (exceptions: L. compacta and L. discreta).

The importance of monoicy and dioicy for explaining range size differences was also shown in a study on the ranges of liverworts species in a lowland cloudforest of French Guiana (Gradstein 2006). It appeared that species occurring in the high canopy of the forest were significantly more often monoicous and had wider ranges than those growing in the forest understory. Whether this correlation also holds for Lejeunea species of Malaysia cannot be determined since the Lejeunea flora of the high canopy of the Malaysian forests has not yet been inventoried.

\section{GEOGRAPHICAL DISTRIBUTION WITHIN MALAYSIA}

Malaysia is divided into two major geographical regions: Peninsular Malaysia which is connected to mainland Asia and East Malaysia (states of Sabah and Sarawak) on the island of Borneo. There are major differences in the tree flora of Peninsular Malaysia and East Malaysia (Saw et al. 2010). In general, East Malaysia harbors a richer tree flora compared to Peninsular Malaysia with Sabah and Sarawak having on average 44\% more species than Peninsular Malaysia (Saw \& Chung 2007). Moreover, the level of endemism is also higher in Sabah and Sarawak with $42 \%$ endemism in seed plants compared to Peninsular Malaysia with about $26.4 \%$ ( $\mathrm{Ng}$ et al. 1990). The higher endemism in Sabah and Sarawak is explained by the presence of higher mountains in Sabah and Sarawak and a greater diversity of soils and geological formations compared to Peninsular Malaysia (Saw et al. 2010).

Based on the present study, the diversity distribution pattern of Lejeunea in Malaysia follows that of the seed plants discussed above, with East Malaysia (Sabah, Sarawak) having 25\% more species than Peninsular Malaysia (Table 2). Of 32 taxa of Lejeunea recorded in Malaysia, 9 are new to Peninsular Malaysia, 3 are new to East Malaysia and 1 is new to Peninsular Malaysia and East Malaysia (Table 2). The greatest diversity is found on Mt. Kinabalu (Sabah) where 27 species have been recorded. This mountain harbors a wide variety of habitats, including well-developed humid montane forests which seem to provide optimal growth conditions for Lejeunea species. In contrast, Peninsular Malaysia has 19 species with 18 of them

Table 3. Number of Lejeunea taxa (species, varieties) reported from the states of Peninsular Malaysia.

\begin{tabular}{lc}
\hline State & Nr of taxa \\
\hline Pahang & 18 \\
Kelantan & 10 \\
Perak & 9 \\
Selangor & 6 \\
Kedah including Pulau Langkawi & 6 \\
Penang & 5 \\
Johor & 3 \\
Perlis & 2 \\
Kuala Lumpur & 2 \\
Negeri Sembilan & 1 \\
\hline
\end{tabular}


being found in the state of Pahang, followed by Kelantan with 10 species and Perak with 9 species. Furthermore, about 5-6 species each are found in the states of Kedah (including Pulau Langkawi), Penang and Selangor, while only one species is recorded from Negeri Sembilan (Table 3). The high number of species recorded from Pahang is probably due to the good road infrastructure in some of the highland areas of the state, e.g., Cameron Highlands, Genting Highlands and Fraser's Hill, making these areas well accessible.

\section{ELEVATIONAL DISTRIBUTION WITHIN MALAYSIA}

The distribution of the species of Lejeunea in Malaysia shows a distinct elevational differentiation (Figs $1 \& 2$ ). The total altitudinal range of the genus extends from sea level to $3000 \mathrm{~m}$ but most of the species occur below $2000 \mathrm{~m}$, like many other members of Lejeuneaceae (Gradstein 1994, 1995). The distribution data show that the range sizes of Malaysian Lejeuneas decline towards higher elevations, with endemic species being found only in montane environments (Figs $1 \& 2$ ). This phenomenon has also been found elsewhere in the tropics (e.g., Gradstein et al. 1989; Piippo 1994; Nöske et al. 2003) and may be explained by the reduced surface area in terms of habitats available in the mountains as compared to the lowlands (Aryanti \& Gradstein 2007). Unexpectedly, the widespread pantropical L. flava was found in Malaysia only in montane environments; elsewhere in the tropics this common species occurs in lowland areas as well (e.g., Reiner-Drehwald 2003).

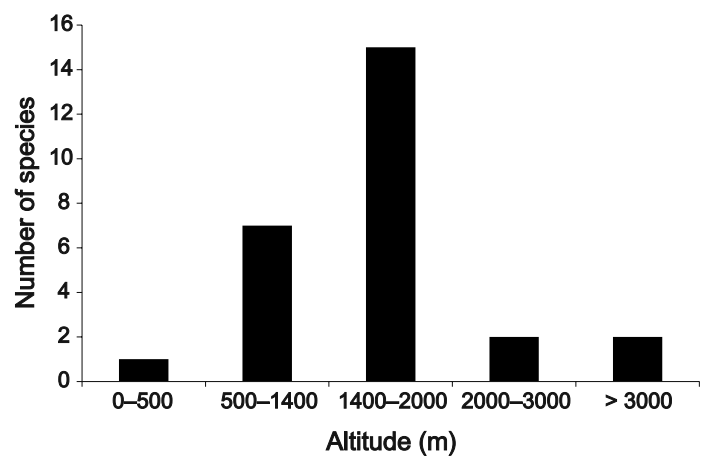

Fig. 1. Altitudinal distribution of Lejeunea species in Malaysia.
Frahm and Gradstein (1991) described five elevational belts of tropical rainforest. Of these, two belts (upper montane, subalpine) are in Malaysia largely restricted to Mt. Kinabalu. Among the Malaysian Lejeunea species, six have very wide elevational ranges (L. compacta, L. exilis, L. papilionacea, L. sordida, L. tuberculosa, L. umbilicata) and occur in most of the rainforest belts described by Frahm and Gradstein (1991). The remaining Lejeunea species have more restricted elevational ranges and occur mainly in one or two belts.

1. LOWLAND RAINFOREST BELT $(0-500 \mathrm{~m})-$ Dense mats of bryophytes are almost lacking in the lowland rainforest. Only one species of Lejeunea in Malaysia, L. anisophylla, is a typical lowland taxon occurring usually below $500 \mathrm{~m}$. This species is very common throughout Malaysia and is known from numerous collections. It is often found on roadside trees, in gardens and in recreational parks, or in other open and often disturbed places. Some other species such as $L$. cocoes and $L$. patersonii can also be found in the lowland rainforest belt although their main occurrence is in the mountains.

2. Submontane Rainforest Belt (500$1400 \mathrm{~m}$ ) - Six species seem to be confined to this belt, viz. L. alata, L. cocoes, L. micholitzii, L. patersonii, L. patriciae and L. tamaspocsii. Submontane rainforests such as occurring on Genting Highlands, Fraser's Hill and Cameron Highlands, are the preferred habitats for some of these species, particularly L. patriciae.

3. LOWER MONTANE RAINFOREST BELT (1400$2000 \mathrm{~m}$ ) - In this elevational belt, tree trunks and branches are covered by dense mats of bryophytes; in addition, vascular epiphytes are abundantly present. About half of the Malaysian Lejeunea species occur in this belt, including $L$. albescens, L. contracta, L. dimorpha, L. dipterota, L. discreta, L. eifrigii, L. exilis, L. flava, L. fleischeri, L. kinabalensis, L. lumbricoides, L. microloba, L. mimula, L. mizutanii, L. pectinella and L. utriculata. In spite of the high diversity, the species occurring here are usually not as common as in the lowlands and some are known from only very few collections (e.g., L. mizutanii). A reason for the relative rareness of the montane species may be the more 


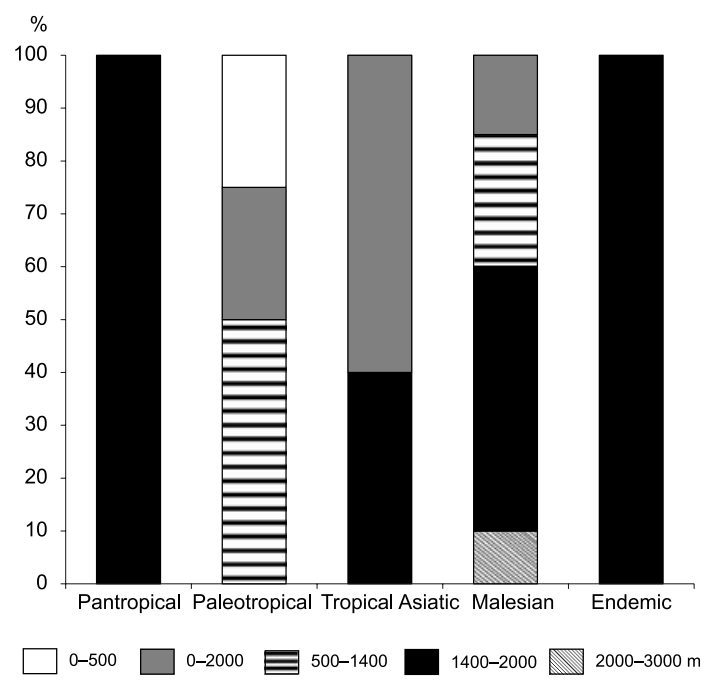

Fig. 2. Altitudinal distribution of Lejeunea species in Malaysia relative to phytogeographical element.

narrow substrate preference of these species. For example, the lower montane L. dimorpha is an obligate epiphyll, growing exclusively on living leaves, whereas $L$. contracta occurs exclusively on rock.

4. UPPER MONTANE RAINFOREST BELT (2000$3000 \mathrm{~m}$ ) - The number of species is reduced radically at this elevation. Thus far, only two species are known only from the upper montane rainforest belt, viz. L. stephaniana and L. gradsteinii. Some species occasionally occur in this belt although they are found mostly in lower montane forest, viz. L. albescens, L. compacta, L. contracta, L. flava, L. lumbricoides, L. mizutanii, L. pectinella and L. utriculata. Most of them have been found on Mt. Kinabalu.

5. SUBALPINE RAINFOREST BELT $(>3000 \mathrm{~m})$ - Some species occasionally extend up to the subalpine belt, e.g., L. compacta, L. lumbricoides and L. stephaniana, but none of the Malaysian Lejeuneas are restricted to this belt.

\section{HABITATS}

Substrate data for Malaysian Lejeunea species (Fig. 3) have been gathered from specimen labels as well as from field observations. Most of the species are epiphytic, growing on bark of tree trunks (corticolous) or on branches (ramicolous), or both. Almost two third (63\%) of $c a$ one thousand specimens examined were collected on trunks, branches and twigs while $17 \%$ were from leaves (epiphyllous), 9\% from rock (saxicolous), $6 \%$ from rotten logs or stumps, $6 \%$ from shrubs, $3 \%$ on forest litter, $2 \%$ from soil or humus (sometimes on soil covering rocks) and $0.7 \%$ on fruiting bodies of fungi. Ten specimens (1.4\%) were from artificial substrate such as metal water pipelines; the rest are from unknown substrates. Several species such as L. patriciae had broad substrate preferences and occurred on bark of trees, shrubs, leaves and decaying logs. Others had more narrow preferences and occurred on only one substrate type. For example, L. dimorpha occurred only as an epiphyll on living leaves, L. lumbricoides was always found hanging down loosely from shrubs or branches, L. mimula occurred exclusively on tree trunks and $L$. contracta grew only on rock.

In general, the Lejeunea species in Malaysia are mostly epiphytic, occasionally saxicolous; terrestrial growth is rare. All species showed a preference for humid tropical rainforest although some common species such as L. anisophylla and L. tuberculosa were often found also in open and disturbed areas such as in gardens. The most common epiphytic species are L. anisophylla, L. flava, L. discreta, L. exilis, L. sordida, L. tuberculosa and L. umbilicata. Of these, L. tuberculosa was represented by the highest number of specimens examined (115), followed by L. flava with 102 specimens. A total of 162 specimens belonging to 20 different species were collected on living leaves. The most common epiphyllous species are L. apiculata, L. dimorpha, L. flava, L. papilionacea, L. patriciae and L. tuberculosa, less commonly epiphyllous are L. gradsteinii, L. kinabalensis, L. mizutanii, L. stephaniana and L. umbilicata. Based on the present study, most of the epiphyllous Lejeunea species are facultative epiphylls and also grow on other substrates. Lejeunea dimorpha was the only species occurring exclusively on living leaves and may be considered obligately epiphyllous. Obligate epiphylls occurring exclusively on living leaves were called 'typically' epiphyllous 


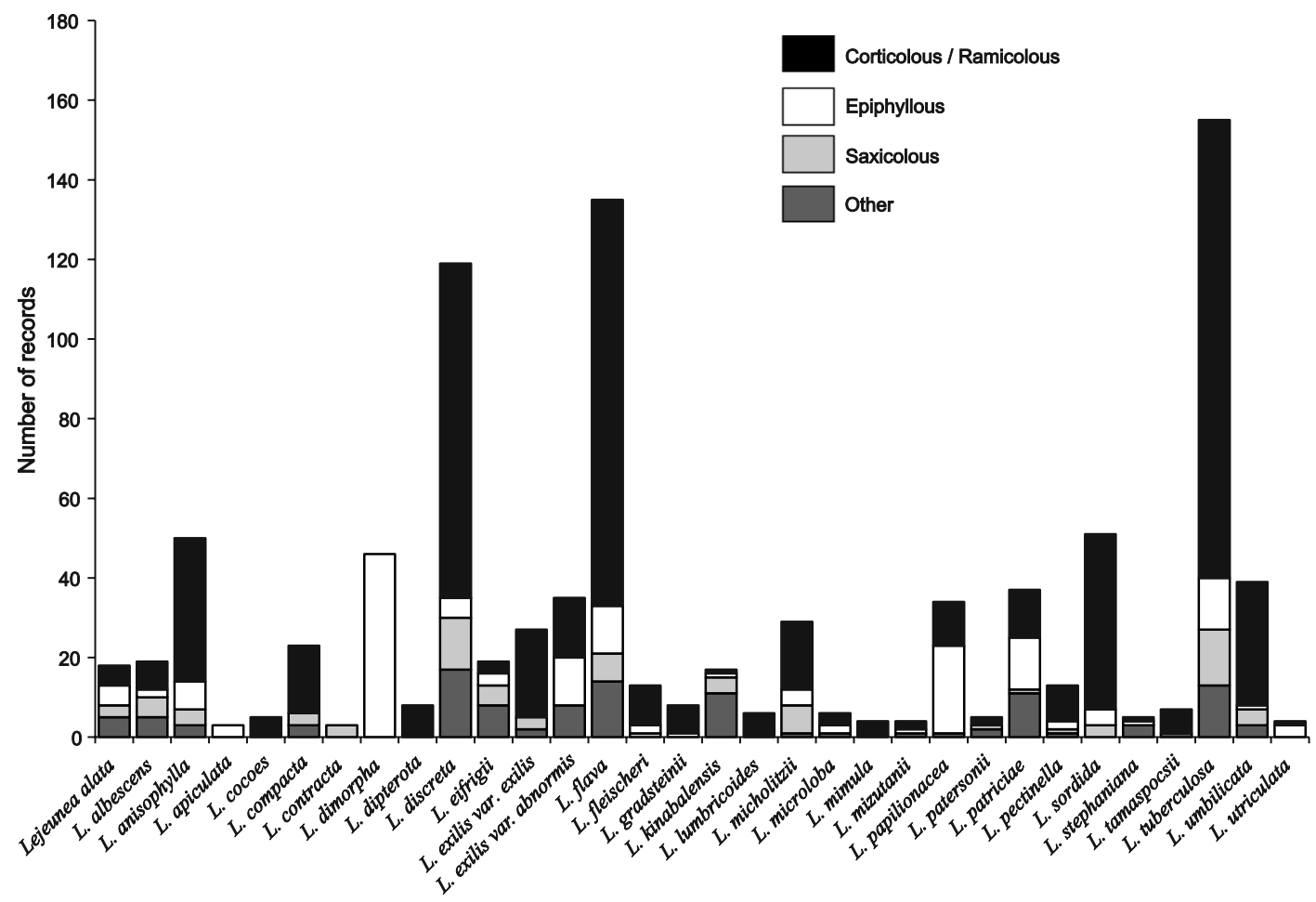

Fig. 3. Substrate preferences of Lejeunea species in Malaysia.

by Gradstein (1994) because obligate epiphylly is difficult to prove. In the case of $L$. dimorpha, however, all specimens examined (46) were from living leaves, most of the time growing together with the well-known epiphyllous moss Ephemeropsis tjibodensis Fleisch. In the literature L. dimorpha has only been recorded from living leaves (Kodama 1976; Pócs et al. 1995; Pócs 1996). Therefore, this species may be considered an obligate epiphyll. Other epiphylls frequently growing associated with the epiphyllous Lejeunea species in Malaysia were members of Cololejeunea, Drepanolejeunea and Leptolejeunea.

As shown by Piippo (1994), Pócs (1996), Zhu and So (2001) and others, epiphyllous species may occur in disturbed habitats or gardens though they are most common in primeval rainforests. This is true in some species of epiphyllous Lejeunea in Malaysia, e.g., L. papilionacea, which was found growing by the roadside in Fraser's Hill but otherwise occurred in virgin rainforests such as at Lanjak
Entimau Wildlife Sanctuary in Sarawak and Gunung Batu Putih in Pahang. However, species that can endure even much greater habitat disturbance are mostly corticolous and ramicolous species, e.g., L. anisophylla and L. tuberculosa (see below). Ten specimens were from artificial substrates such as metal water pipelines and two were from fungi indicating that some species of Lejeunea favor smooth surfaces. Lejeunea kinabalensis grows on forest litter, among dried, decaying leaves, and on roots on earth banks. All species show a preference for humid tropical rainforest although some common species such as L. anisophylla and L. tuberculosa are often found also in open and disturbed areas such as in gardens.

\section{NEW SPECIES}

In the course of this study one species was collected which appeared to be new to science. The species is named in the honor of Professor 
Tamás Pócs in recognition of his major contributions to tropical bryology, especially the family Lejeuneaceae.

Lejeunea tamaspocsii G. E. Lee, sp. nov.

TYPE: PENINSULAR MALAYSIA, PAHANG, Genting Highlands, Goh Tong Jaya, area around the waterfall, 845 m, 3 March 2011, G.E. Lee 2194 (HOLOTYPE, UKMB; ISOTYPE, EGR). (Fig. 4).

Plants autoicous, relatively small, $0.8-1.0 \mathrm{~mm}$ wide, light green when fresh to brown when dry, irregularly and slightly branched, branches erectspreading to widely spreading with three small basal collar lobes. Stems $0.07-0.10 \mathrm{~mm}$ in diameter, about 5-6 cells high in cross-section, epidermal cells 7, 25-40 $\mu \mathrm{m}$ wide (optical view), medullary cells $4-5,13-18 \mu \mathrm{m}$ in diameter (cross section). Leaves distant to contiguous, \pm erect-spreading, convex when moist. Leaf lobes $0.5-0.6 \mathrm{~mm}$ long, 0.4-0.5 mm wide (when flattened), ovate, asymmetrical with strongly arched dorsal margin and straight to slightly curved ventral margin, leaf apex narrowly rounded, flat, sometimes recurved, leaf margin crenulate due to slightly projecting marginal cells; the ventral margin forming an angle of $100^{\circ}-150^{\circ}$ with the keel when flattened; insertion line about 13 lobe cells long. Leaf cells rather uniform, gradually becoming smaller towards the leaf margin, usually quadrate to pentagonal, irregularly quadrate to rectangular towards the leaf margin; apical cells $25-30 \mu \mathrm{m}$ long and 13-25 $\mu \mathrm{m}$ wide, median cells $25-38 \mu \mathrm{m}$ long and $18-25 \mu \mathrm{m}$ wide, basal cells $38-50 \mu \mathrm{m}$ long and 20-25 $\mu \mathrm{m}$ wide; cell walls hyaline, with well-developed trigones and occasionally with intermediate thickenings, 1-2 per cell, $0-1(-2)$ between 2 adjacent trigones; cuticle rough by numerous minute papillae; oil bodies not seen. Leaf lobules rarely reduced, 0.15 $0.20 \mathrm{~mm}$ long and $0.12-0.15 \mathrm{~mm}$ wide, to $1 / 3$ the length of the lobe, at an angle of about $60^{\circ}$ to the stem, ovate, inflated along the keel, apex obliquely truncate, keel curved, free margin flat, sometimes incurved fully; apical tooth 20-25 $\mu \mathrm{m}$ long, oblong, erect and obtuse, margin between tooth and sinus 3 cells long, without large rectangular 'disc cell' distal to the apical tooth, cell below the apical tooth $30 \mu \mathrm{m}$ long and $25 \mu \mathrm{m}$ wide. Underleaves small, ca $0.1 \mathrm{~mm}$ long, $0.1-0.15 \mathrm{~mm}$ wide, up to 2 times wider than the stem, distant, suborbicular to wider than long, not covering the lobules, bilobed, lobes to $1 / 2$ of underleaf length, about 4 cells wide, somewhat triangular, distant, sinus narrow to broad, acute to slightly obtuse, widely V-shaped; underleaf margin strongly crenulate, base straight, two large basal underleaf cells differentiated; underleaves attached to the stem by 2 superior central cells. Androecia $0.2-0.3 \mathrm{~mm}$ long, ca $0.3 \mathrm{~mm}$ wide with bracts, usually intercalary on main shoots, rarely on short or long lateral branches; male bracts in 2-3 pairs, margin entire to somewhat crenulate, without wing, apex obtuse, keel inflated; male bracteoles 1, smaller than underleaf, margin crenulate; antheridia not seen. Gynoecia usually on main shoots, occasionally on short or long branches, with one innovation, the innovation usually fertile; female bracts loosely arranged, slightly smaller than vegetative leaves, erect-spreading when moist, lobes $0.4-0.5 \mathrm{~mm}$ long, ca $0.2 \mathrm{~mm}$ wide, oblong to obovate, apex acute, margin crenulate; lobules $c a 0.3 \mathrm{~mm}$ long, $0.07-0.09 \mathrm{~mm}$ wide, rarely reduced, $1 / 2$ the width and 2/3-3/4 the length of the lobe, oblong, apex obtuse, keels straight, smooth, $0.25-0.30 \mathrm{~mm}$ long; female bracteoles $0.4-0.5 \mathrm{~mm}$ long, $0.15-0.20 \mathrm{~mm}$ wide, $1 / 2$ the length of the perianth length, oblong with tips acute, lobes to $1 / 4$ of female bracteole length, contiguous, sinus narrow, acute, margin crenulate. Perianths $0.75 \mathrm{~mm}$ long, $0.3 \mathrm{~mm}$ wide, emergent to $1 / 2$ of the perianth length, oblong, with 5 keels, the keels 2-winged and sometimes mammillose, wings 1-2 cells wide, lateral keels

Fig. 4. Lejeunea tamaspocsii G. E. Lee, sp. nov. A - Part of plant in ventral view, B \& C - leaves, D, H \& I - underleaves, $\mathrm{E}$ - median cells of leaf lobe, $\mathrm{F}$ - cross-section of stem, $\mathrm{G}$ - upper part of leaf lobule (hyaline papilla shown by arrow), $\mathrm{J}-$ stem portion and leaf lobule (hyaline papilla shown by arrow), K \& M - perianths, L - cells of perianth keel, $\mathrm{N}-$ perianth with bracts and bracteole, $\mathrm{O}$ - cross-section of perianth, $\mathrm{P}$ - upper portion of perianth. All figures drawn from the holotype, G. E. Lee 2194 (UKMB). 


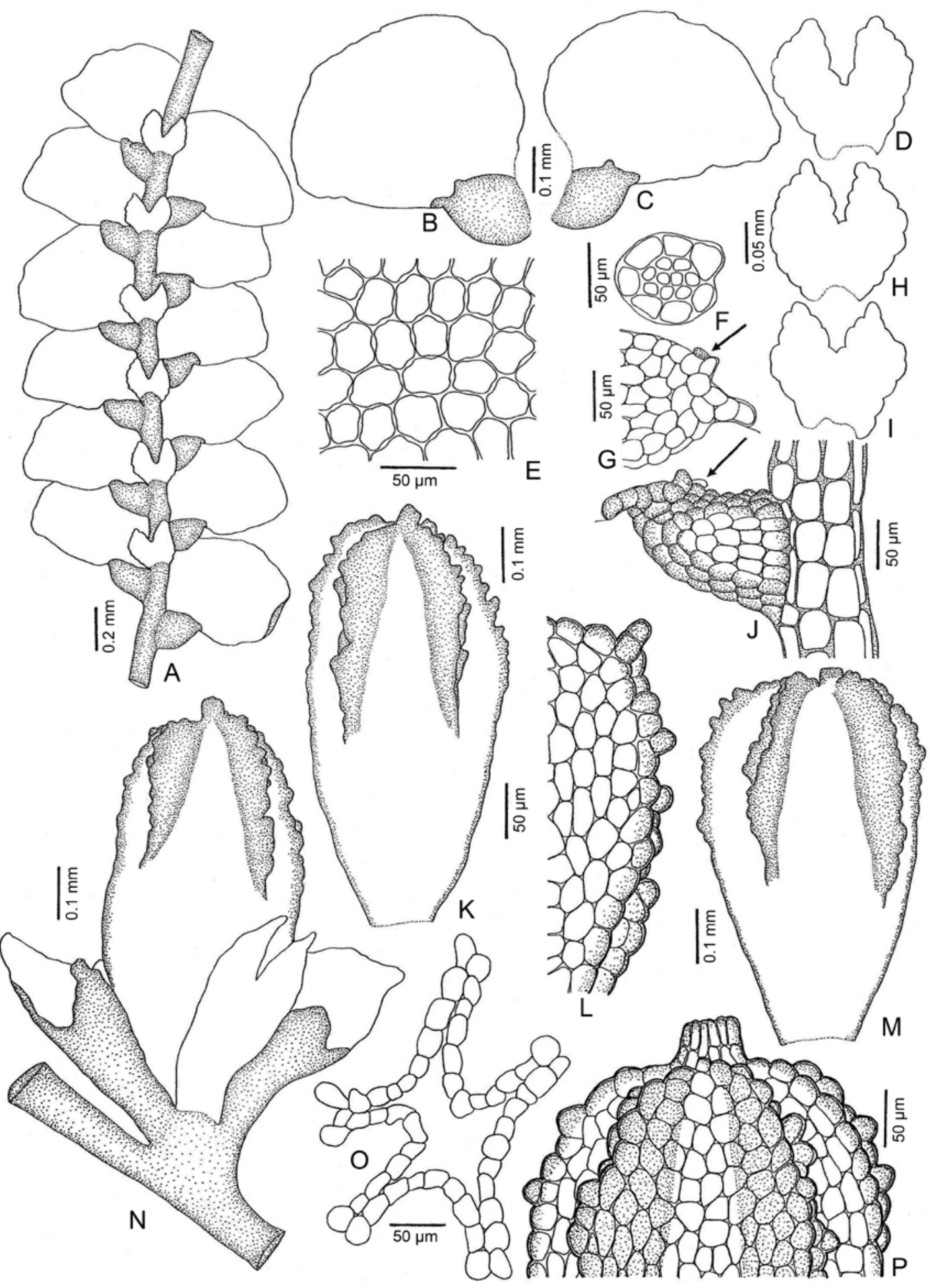


sometimes with 1-3 celled cilia; beak 2-3 cells long. Sporophyte: seta to $0.7 \mathrm{~mm}$ long; capsule $c a$ $0.4 \mathrm{~mm}$ in diameter, valves $0.3 \mathrm{~mm}$ long, $0.2 \mathrm{~mm}$ wide at middle, widely spreading after dehiscence; elaters $\mathrm{ca}$ 0.15-0.25 mm long; spores rectangular to irregular-shaped, 38-50 $\mu \mathrm{m}$ long and 20-25 $\mu \mathrm{m}$ wide. Vegetative propagation not seen.

DISTRIBUTION AND HABITAT. Only known from Malaysia (Peninsular Malaysia, Sabah), growing on tree trunks and rotten stumps in open areas and on shaded mountain slopes, 800-1600 m.

FURTHER SPECIMENS EXAMINED. MALAYSIA. KELANTAN: Gua Musang, foot of Gunung Chamah, Dakota trail, 770 m, 2011, A. Damanhuri 11-466 (UKMB). PAHANG: Fraser's Hill, road to Clock Tower and Post Office, 1120 m, 2009, G. E. Lee 1423 (UKMB); Cameron Highlands, Robinson Waterfall, 1340 m, 2009, G. E. Lee 2274 (UKMB); Mentigi trail, 1365 m, 2009, G. E. Lee 2275 (UKMB). SABAH: Mt. Kinabalu, along road from park headquarters to Timpohon gate, $1530 \mathrm{~m}, 2010$, G. E. Lee 1732 (UKMB).

Characteristic features of Lejeunea tamaspocsii are: 1) the asymmetrical leaf lobes with arched dorsal margin and straight to slightly curved ventral margin and with a narrowly rounded apex; 2) the small, distant underleaves with coarsely crenulate margins; 3 ) the rough cuticle covered by minute papillae; and 4) the perianths with 2-winged keels, the wings sometimes with 2-celled cilia. Two-winged perianth keels have previously been recorded from some neotropical members of the genus Crossotolejeunea, a genus now included in Lejeunea (Reiner-Drehwald \& Goda 2000), but are rare among Malaysian Lejeuneas where 2-winged perianth keels were only observed in L. tamaspocsii and L. dipterota (Eifrig) G. E. Lee. The latter species differs from L. tamaspocsii by numerous features and relationships between the two taxa are distant (Lee, in press; Lee et al., in prep.). Among the Malaysian Lejeuneas, the new species is most closely related to L. patriciae A. Schäfer-Verw., which was recovered as sister to L. tamaspocsii in a phenetic and phylogenetic analysis (Lee et al., in prep.). Lejeunea patriciae is easily recognized from $L$. tamaspocsii by having more symmetrical leaf lobes with a broadly rounded apex, a smooth cuticle, underleaf margins hardly crenulate, perianth keels not 2 -winged and, most notably, by the frequent occurrence of short rhizoids at the apical margins of leaf lobes. In L. tamaspocsii marginal rhizoids on leaf lobes were never observed.

ACKNOWLEDGEMENTS. This study was financially supported by the National Science Foundation (NSF) of Malaysia and by the Dana Operasi UKM-OUP research fund awarded to Emer. Prof. Dato' Abdul Latiff Mohamed. We are grateful to Elena Reiner-Drehwald and Rui-Liang Zhu for constructive criticism on the manuscript. The first author expresses her thanks to Prof. Tamás Pócs for help with literature and to her husband, Daniel Tang, for fieldwork assistance.

\section{REFERENCES}

ARYANTI N. S. \& GRADSTEIN S. R. 2007. Wallace's line and the distribution of the liverworts of Sulawesi. Cryptog. Bryol. 28: 3-14.

EIFRIG H. 1937. Monografische Studien über die Indomalayischen Arten von Taxilejeunea. Ann. Bryol. 9: 73-114.

FrAHM J. P. \& GRADSTEIN S. R. 1991. An altitudinal zonation of tropical rain forests using bryophytes. J. Biogeogr. 18: 669-678.

Gradstein S. R. 1994. Lejeuneaceae: Ptychantheae, Brachiolejeuneae. Fl. Neotrop. Monogr. 62: 1-216.

GRADSTEIN S. R. 1995. Diversity of Hepaticae and Anthocerotae in montane forests of the tropical Andes. In: S. P. Churchill, J. L. Luteyn, H. BAlslev \& E. Forero (eds), Biodiversity and conservation of neotropical montane forests, pp. 321-334. New York Botanical Garden, Bronx, U.S.A.

Gradstein S. R. 2006. The lowland cloud forest of French Guiana - A liverwort hotspot. Cryptog. Bryol. 27: 141-152.

Gradstein S. R., Pócs T. \& VÁna J. 1983. Disjunct Hepaticae in Tropical America and Africa. Acta Bot. Hung. 29: $127-171$.

Gradstein S. R., vAN REENEN G. B. A. \& GRIFFin D. 1989. Species richness and origin of the bryophyte flora of the Colombian Andes. Acta Bot. Neerl. 38: 439-448.

HeinRICHS J., LindNer M., Groth H., Hentschel J., FeldBERG K., RENKER C., ENGEL J. J., VON KONRAT M., LONG D. G. \& SCHNEIDER H. 2006. Goodbye or welcome Gondwana? - insights into the phylogenetic biogeography of the leafy liverwort Plagiochila with a description of Proskauera, gen. nov. (Plagiochilaceae, Jungermanniales). Pl. Syst. Evol. 258: 227-250. 
KoDAMA T. 1976. Three new species of Lejeuneaceae from Kinabalu National Park, Sabah (North Borneo). J. Hattori Bot. Lab. 41: 381-387.

LEE G. E. In press. A systematic revision of the genus Lejeunea Lib. (Marchantiophyta: Lejeuneaceae) in Malaysia. Cryptog. Bryol. 34(4).

LONGTON R. E. \& SChUster R. M. 1983. Reproductive Biology. In: R. M. SCHUSTER (ed.), New Manual of Bryology. 1: 386-462. Hattori Botanical Laboratory, Nichinan, Japan.

MiZUTANI M. 1963. On some Indian species of the family Lejeuneaceae described by W. Mitten. J. Hattori Bot. Lab. 26: $171-184$.

MizUTANI M. 1966. Epiphyllous species of Lejeuneaceae from Sabah (North Borneo). J. Hattori Bot. Lab. 29: 153-170.

MizUTANI M. 1970. Lejeuneaceae subfamilies Lejeuneoideae and Cololejeuneoideae from Sabah (North Borneo). J. Hattori Bot. Lab. 33: 225-265.

NG F. S. P., Low C. M. \& Mat AsRi N. S. 1990. Endemic trees of the Malay Peninsula. Research Pamphlet 106, Forest Research Institute Malaysia, Kuala Lumpur.

NöSke N., Gradstein S. R., KÜRschner H., PAROlly G. \& TORRACCHI S. 2003. Cryptogams of the Reserva Biológica San Francisco (Prov. Zamora-Chinchipe, Southern Ecuador). I. Bryophytes. Cryptog. Bryol. 24: 15-32.

PIIPPO S. 1994. On the bryogeography of Western Melanesian Lejeuneaceae, with comments on their epiphyllous occurrence. Trop. Bryol. 9: 43-57.

PIIPPO S. \& KopOnen T. 1997. On the phytogeographical biodiversity of Western Melanesian mosses. J. Hattori Bot. Lab. 82: 191-201.

Pócs T. 1988. Biogeography of the Cuban bryophyte flora. Taxon 37: 615-621.

Pócs T. 1996. Epiphyllous liverwort diversity at worldwide level and its threat and conservation. Anales Inst. Biol. Univ. Nac. Autón. México, Bot. 67: 109-127.

Pócs T. 2008. Bryophytes from the Fiji Islands, IV. The genus Frullania Raddi (Jungermanniopsida), I., with description of F. vivipara Pócs, spec. nov. Fieldiana Bot. 47: 147-158.
Pócs T. 2010. On some new or less known Lejeunea (Lejeuneaceae, Jungermanniopsida) species in tropical Africa. East African Bryophytes, XXVII. Nova Hedwigia Beih. 138: 99-116.

Pócs T., PiIPPo S. \& Mizutani M. 1995. Bryophyte flora of the Huon Peninsula, Papua New Guinea. LVI. Preliminary contributions on Lejeuneaceae (Hepaticae) 2. Ann. Bot. Fenn. 32: 259-268.

REINER-DREHWALD E. 2003. Lejeunea. In: S. R. GRAdSTEIN \& D. P. CostA, The Hepaticae and Anthocerotae of Brazil. Mem. New York Bot. Gard. 87: 155-163.

ReINER-Drehwald M. E. 2009. Lejeunea adpressa Nees (Lejeuneaceae), a widely distributed species of tropical America. Cryptog. Bryol. 30: 329-336.

ReINER-Drehwald M. E. \& Goda A. 2000. Revision of the genus Crossotolejeunea (Lejeuneaceae: Hepaticae). J. Hattori Bot. Lab. 89: 1-54.

SAW L. G. \& ChUnG R. C. K. 2007. Towards the flora of Malaysia. In: L. S. L. ChUA, L. G. KIRTON \& L. G. SAW (eds), Proceedings of seminar and workshop on the status of biological diversity in Malaysia and threat assessment of plant species in Malaysia, pp. 203-219. Forest Research Institute Malaysia, Kuala Lumpur.

Saw L. G., Chua L. S. L., Suhaida M., Yong W. S. Y. \& HAMIDAH M. 2010. Conservation of some rare and endangered plants from Peninsular Malaysia. Kew Bull. 65: $681-689$.

SCHÄFER-VERWIMP A. 2006. New national and regional bryophytes records 14: Lejeunea patriciae. J. Bryol. 28: 272.

SCHUSTER R. M. 1980. The Hepaticae and Anthocerotae of North America. 4. Columbia University Press, New York.

Stephani F. 1915. Species Hepaticarum V: Lejeunea. Geneve et Bale, Lyon.

VAN ZANTEN B. O. \& GRAdSTEIN S. R. 1988. Experimental dispersal geography of Neotropical liverworts. Nova Hedwigia Beih. 90: 41-94.

VAN ZANTEN B. O. \& PÓCs T. 1981. Distribution and dispersal of bryophytes. Advances Bryol. 1: 479-562.

ZHU R. L. \& So M. L. 2001. Epiphyllous liverworts of China. Nova Hedwigia Beih. 121: 126-162. 